\title{
A Practical Exploration of the Moral Education for Foreign Language Majors
}

\author{
Yunfei Ma \\ College of Humanities and Social Sciences, \\ Tianjin Agricultural University \\ No.22, Jinjing Road, Tianjin 300384, China \\ esther054000@163.com
}

\begin{abstract}
Moral education is an indispensable part of higher education. According to the characteristics of foreign language majors, employing the talent cultivation mode - the combination of moral education and professional education is not only beneficial to the development of moral education, but also to make the moral education effective in practice. This paper analyzes the importance of moral education, and discusses how to better coordinate the moral education and professional education combining with practice. It suggests that the fusion of moral education and professional education can make the two develop better and get better educational result.
\end{abstract}

Keywords-foreign language majors; moral education; professional education; practical exploration

\section{INTRODUCTION}

Teacher's responsibility is to impart knowledge and educate people. Educating people is the first, and teaching is the second. If a university foreign language major teacher does teaching job and serves as head teacher concurrently, he can have more opportunities to contact with students, better combine imparting knowledge with educating people, and combine theory with practice to make greater contribution to the cultivation of excellent talents [1].

\section{PAYing ATTENTION TO THE CULTIVATION OF GOOD MORAL}

\section{CHARACTER AND PLACING EQUAL EMPHASIS ON MORAL AND}

\section{INTELLECTUAL EDUCATION}

\section{A. Cultivating good moral character first}

The fundamental task of education is to cultivate good moral character. Universities undertake the task of cultivate talents. Training students includes not only the teaching of professional knowledge but also the shaping of students' personality, morality, and behavior standards. Moral education should always be one of the important jobs of universities. And universities have to carry out it unremittingly. In recent years, colleges and universities have carried out various forms of moral education and achieved remarkable results. The ideological and cultural qualities of university students have been improved significantly and they enter the society as qualified personnel when they graduate. Moral education has also made great contributions to the maintenance of school and social stability [2].

One of the most important characteristics of teacher's profession is to have a positive impact on students through his own ideals, beliefs, life attitudes and moral qualities. Therefore, teachers should keep "being a model of virtue for students" in mind, instruct and influence students by their words and deeds, and penetrate moral education into all aspects of education. The head teacher should adhere to the principle cultivating good moral character first and pay attention to cultivate students' good moral character. If teachers ask students to obey the rules and regulations of school, they should set a good example for students taking the lead in compliance with the rules and regulations of the school. The head teacher should lead the students to actively participate in various activities of the society and school, such as participation in donation activities. Such kind of meaningful activities are helpful to educate students to devote love to others and repay the society with a grateful heart. Foreign language majors understand western culture by the western festivals, so moral education can also be carried out on some western festivals, such as Mother's Day. Special moral education can be conducted on the Mother's Day. Teachers can ask students to read some touching Chinese or English articles on the maternal love, and let students talk about how to appreciate mother. Such kind of moral education can cultivate students' gratitude for the society, country, collective and family. Teachers can also tell students their views on the maternal love with their own experience. Using examples to infect students will be able to achieve very good educational results. In addition, teachers should always grasp the moral education of students in order to achieve good results.

The modern foreign language majors of China generate diversified ideological concept, values and behavior in the social environment intertwined with various realistic factors. These ideas, consciousness and behavior affect the role of the student in the traditional social scene and blur the boundaries between different roles and behavior, resulting in students' loss of standards and specifications in different role conversion. And it will also cause social and psychological conflict. Correcting and guiding the foreign language majors to 
establish proper world outlook, outlook on life and values have become an important task for university teachers [3].

\section{B. The combination of moral education and professional}

\section{education}

Moral education in universities has always been the main field of citizen moral education in china. For a long time, the focus of moral education in universities is the handling of interpersonal relationships in the real life, the promotion of the spirit of collectivism and the continuation of the whole human race [4]. UNESCO has advocated four things: learn to learn; learn do: learn to together: learn to be. Among them, learn to be is the most important. That means the sole aim of learning is learning to be an upright man just as what the ancients said. Teachers can strengthen students' ideological and cultural education through professional teaching and extracurricular practical activities. Mr. Lin Yutang said: "Be familiar with Chinese and Western cultures, as one comment on universal articles." The modern foreign language majors must learn foreign cultures. According to these professional characteristics, teachers should educate students to pay attention to the differences between Chinese and Western cultures and at the same time not to forget to inherit the excellent Chinese traditional culture. Moral education permeates all aspects of professional education through strengthening the education of patriotism, collectivism and Chinese traditional virtues. The combination of moral education and professional education can help students establish a correct outlook on life, world outlook and values. For example, there is a chapter in the course of American literature. The chapter is on Philip Freneau who has been entitled "father of American Poetry". Freneau focused on the description of the American native cultural landscape and laid the foundation for the development of the localization of American poetry. Freneau loves and spreads his own native culture. And he is good at finding miracles from ordinary things. His humanistic feelings and unique perspective are well worth learning. In order to educate students to learn from Freneau, teachers can make an in-depth study of Freneau's poetry, deepen the teaching content further and develop the teaching material that covers moral education. And teacher can also try inspiring students to write about the special plants or scenery of campus and hometown so as to stimulate students to love school, hometown, and motherland.

\section{PROMOTE THE CONSTRUCTION OF CLASS AND LEARNING}

\section{ATMOSPHERE BY PROFESSIONAL STUDY}

When teachers carry on the moral education to the student, they should also be good professional tutor of students. In the theoretical and practical teaching of foreign language majors, there are a lot of teaching tasks need to be done with the team cooperation, such as foreign language drama, debate competition, Model United Nations, etc. In the completion of each professional work, teachers should consciously encourage students to help each other, learn to share and undertake, establish a sense of responsibility, and develop a rigorous and pragmatic work style. Teachers can ask students to write semester summary and future planning in foreign language to train students' foreign language writing ability and the ability of summarizing and planning. Encouraging students to exchange foreign novels and learning experience can cultivate students' spirit of selfless dedication and good class and learning atmosphere.

For example, teachers of listening courses can require students to practice listening every day and write listening log during the course of teaching. Students generally reflect this approach is very effective and help to improve the level of listening and develop good learning habits. After the end of the listening course, the students want to continue to make the listening $\log$, but they cannot insist on it without teacher's supervision. According to the desire of students, even if teachers do not teach the listening course, they can still ask the students to write the listening log and check them regularly as head teacher. Teachers can also buy some stationery to reward the students who write the listening log seriously. As a result, the enthusiasm of the students has been mobilized and the class can also form a kind of learning atmosphere of "competing, learning, catching and surpassing". Teachers should encourage students to participate in various activities organized by schools or social organizations to enhance their abilities, such as large-scale activities volunteer selection. Foreign language majors can use their professional advantage like mastery of foreign languages and familiarity with foreign cultures and customs and be translators in various international activities and conferences providing language services.

\section{MORAL EDUCATION IN FOREIGN LANGUAGE MAJORS'}

\section{INTERNSHIP AND EMPLOYMENT}

Through the effective combination of moral education and foreign practice, it is practical to improve the quality of ideological and political education in the practice of foreign language majors. Foreign language majors are more special than other majors. Because of their professional characteristics, they stand in the forefront of international exchanges, are the most closely linked with the foreign countries and are talent reserves of the Chinese and foreign exchanges. Therefore, they are easy to be influenced by the ideological values, and prefer to compare China and western countries. Because the students are lack of social experience, they cannot recognize the foreign cultures reasonably enough. So it is necessary to make foreign language majors accept Chinese cultural identity more than other majors through solid moral education. They can avoid the blind worship of Western cultures with patriotic enthusiasm [5]. Because of the particularity of the professional there are lots of opportunities of foreign exchanges for foreign language majors. They contact with foreign teachers in oral English course, interact with the visiting foreign teachers and students, and many universities also organize foreign language majors to visit foreign countries in winter and summer vacation. It is necessary for the teachers to carry out the education of foreign etiquette and taboos before the foreign exchange. For example, respect the social habits of Westerners, do not ask Westerners' age, marriage, income, etc. The topic of conversation should not involve politics, religion, and sex etc. It is a good time to carry out patriotic and traditional culture education before the foreign exchange. The teacher should indicate to the students that they should pay attention to their behavior in the occasion of foreign affairs, because 
everyone not only represents himself, but also represents the nation. As a contemporary Chinese university student, one should always not to forget to show his self-confidence, self-improvement, optimistic and good image. At the same time, foreign language majors should not forget to spread Chinese traditional culture, which are a glorious historical mission undertaken by foreign language majors and a special mission endowed by the major.

In the employment guidance for foreign language majors, it is necessary to increase the content of the professional ethics education of foreign affairs and highlight the pertinence. Professional ethics is the essential quality of the university students who are faced with the employment. The professional ethics refers to the moral norms that people should abide by in their professional activities. Different enterprises have different professional ethics. Foreign language majors with the advantages of foreign language, more students choose to work with foreign affairs, foreign trade, or other related work after graduation. Teachers should pay attention to training students to have a strong political position in employment guidance education. In the professional ethics of foreign affairs, employees engaged in foreign affairs are required to be loyal to the motherland and people, and consciously safeguard the honor of motherland, the dignity of nation and the interests of people. At the same time, teachers should pay more attention to the cultivation of students' confidence in Chinese culture, and spread Chinese traditional culture in the process of collision between different cultures. Foreign language majors should strictly abide by the discipline of foreign affairs, not disclose the secrets of the party and state, and abide by the laws and regulations of other countries [6].

\section{HUMANISTIC MANAGEMENT AND CARE}

Head teachers should constantly improve their management level and art. And speaking of the class management, head teachers can put the regular management, strict management and scientific management into practice. For the students' daily attendance management, teachers can implement a "class log system", preparing a special notebook as "class log". Everyone can write his genuine feelings, wishes and opinions on the construction of class on it in foreign language. Each class's routine task and chore and class meeting with special theme must be recorded in detail. Students' learning and participation in various activities are to be recorded as an important reference for the evaluation of students at the end of the semester. At the same time, corresponding supervision system should be established. Teachers should periodically check the class log, write comments and express expectations and good wishes for the class. The class log can become a link between teachers and students. After the students graduate, it can also become good memories between teachers and students. Teachers should pay attention to observing the trend of the class, understanding students' thinking and protect the privacy of students. For the students who have introverted personality and a tendency to depression, teachers should pay attention to enlightening them in the proper way or seek help from the professional psychologist to counsel them if necessary. In the cross-cultural learning and living environment, the network plays an important role in the dissemination of information, and also provides abundant learning resources for foreign language majors. However, some information contains various negative, unhealthy and decadent ideas, which erode the students' thinking and shake their socialist ideals and beliefs. Therefore, teachers should actively guide students to use the network reasonably [7].

\section{CONCLUSION}

Teachers who love their students should help them become better. Teachers who love their students should become better together with them. Good moral education requires teachers to do better on their own first and imperceptibly influence and educate students through words and deeds. Teachers should research absorbedly and try to explore the content of professional education that can be fused with moral education. Treat every student with love, confidence and patience, and create a positive and vibrant class to enable each student to fully display their talents and unique charm.

\section{ACKNOWLEDGMENT}

This research was financially supported by China Agricultural Association funded project: "research on the strategy of universities agricultural think tank construction from the international perspective" (PCE1401); the National Educational Science "the 12th Five Year Plan" 2014 key project of Ministry of Education: "research and formulation of Common Chinese Framework of Reference for English level" (DIA140304).

Ma Yun-Fei (1977 - ), female, the Han nationality, from Tianjin. Lecturer of College of Humanities of Tianjin Agricultural University, master of English language and literature. Research interests: the British and American literature, English education.

\section{REFERENCES}

[1] Yun-Fei Ma, "On an English Major Teacher Serving as Head Teacher Concurrently," Education Teaching Forum, the 18th issue, pp. 279-281, August 2012.

[2] Lijia Yin, "On the Establishment of Moral Education System in Chinese and Foreign Universities," Asia-Pacific Education, pp. 162-163. DOI:10.16550/j.cnki.2095-9214.2016.18.133

[3] Tao Wang and Chun Zhang, "A study on the interactive system of ideological and political education and psychological health education for foreign language majors in Colleges and Universities," Economic Research Guide, the 13th issue, pp. 302-303, 2012.

[4] Xunfang Zhou, "Moral Education in the University and Construction of Eco-culture," Journal of Central South University of Forestry \& Technology (Social Sciences), the 2nd issue, vol. 6, pp. 182-185, April 2012

[5] Boyu Long and Li Liu, "On Carrying out the Ideological and Political Education of the College Foreign Language Majors in the Overseas Internship (Faculty of Foreign Languages, Chengdu University, Chengdu, Sichuan, China)," Education and Teaching Research, the 9th issue, vol. 29, pp. 57-60, September 2015

[6] Xin Liu and Lin Shi, "The Ideological and Political Education on Vocational Counsel for Foreign Language Majors-Methods and Countermeasures," Employment Guidance, the 23rd issue, pp. 42-48, 2015.

[7] Xianwei Zhao and Juan Zhou, "Research on the methods of ideological and political education for foreign language majors in the new era," Journal of Hubei University of Economics (Humanities and Social Sciences), the 9th issue, vol. 12, pp. 129-130, September 2015. 